\title{
Fire performance of metal-free timber connections
}

1 Daniel Brandon MSC

PhD student, Department of Architecture and Civil Engineering, BRE Centre for Innovative Construction Materials, University of Bath, UK

2. Cristian Maluk MSc(Hons), PhD

Research Associate, BRE Centre for Fire Safety Engineering, School of Engineering, University of Edinburgh, UK

3 Martin P. Ansell BSC, PhD, FIMMM

Reader in Materials, Department of Mechanical Engineering, BRE Centre for Innovative Construction Materials, University of Bath, UK

4 Richard Harris BSC, CEng, FICE, FIStructE, FIWSC

Professor, Department of Architecture and Civil Engineering, BRE Centre for Innovative Construction Materials, University of Bath, UK
5 Pete Walker BSC, PhD, MIEAust, CPEng, MICE, CEng Professor, Department of Architecture and Civil Engineering, University of Bath, UK

6 Luke Bisby BEng, MScEng, PhD, PEng

Professor, BRE Centre for Fire Safety Engineering, School of Engineering, University of Edinburgh, Edinburgh, UK

7 Julie Bregulla Dipl-Ing, PhD, CEng, MICE Director, Building Technology Group, BRE, Watford, UK
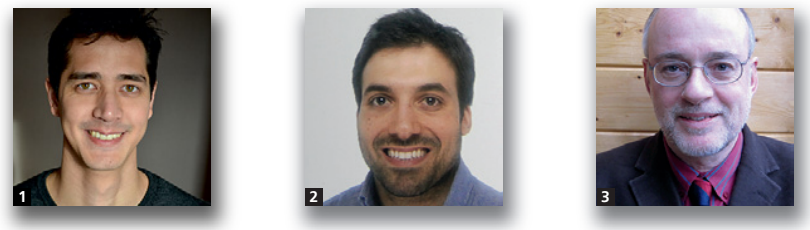

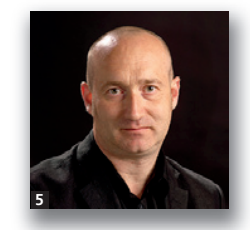

.
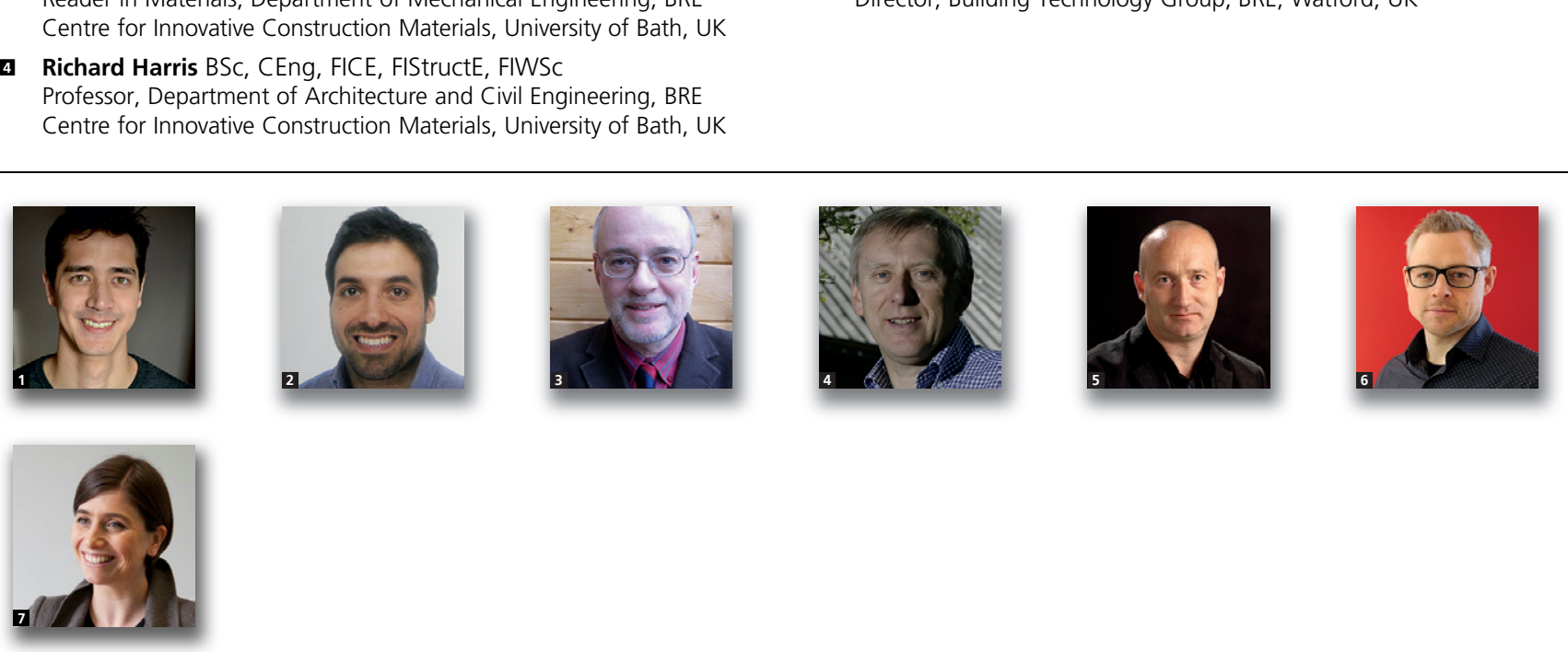

The fire performance of heavy timber frame structures is often limited by the poor fire performance of its connections. Conventional timber connections, dowelled or toothed plate connections typically use steel as a connector material. In a fire, the steel parts rapidly conduct heat into the timber, leading to reduced fire performance. Replacing metallic connectors with alternative non-metallic, low thermal conductivity connector materials can, therefore, lead to improved connection performance in fire. This paper presents an experimental study into the fire performance of metal-free timber connections comprising a hot-pressed plywood flitch plate and glassfibre-reinforced polymer dowels. The thermal behaviour of the connections at elevated temperatures is studied using a standard cone calorimeter apparatus and a novel heat transfer rate inducing system. The latter is a fire testing system developed at the University of Edinburgh. The mechanical behaviour of the connection during severe heating was also studied using an environmental chamber at temperatures up to $610^{\circ} \mathrm{C}$. The results demonstrate that heat transfer in the non-metallic connections is governed by the thermal properties of the timber, resulting in significant enhancements in connection fire performance.

\section{Introduction}

The growing use of engineered timber structures for the design of high-rise buildings (more than five storeys high) presents fundamental challenges for structural fire-safe design (Aseeva et al., 2014). Specifically, heavy timber, referring to structural timber elements of large dimensions (generally above $80 \mathrm{~mm}$ ), is now widely used in commercial and industrial buildings as beams, columns or members of trusses (Östman et al., 2010). It has become generally accepted that heavy timber performs well during and after fire (Buchanan, 2002), as the outer, charred, material becomes a natural insulator for the structural element. However, the fire behaviour of the connections often limits the fire performance of heavy timber structural systems. 
During the past couple of decades, numerous research projects have aimed at identifying the fire risks and hazards associated with technological innovations in the use of timber in high-rise buildings (Gerard et al., 2013). For example, in recent years, research findings have shown that the fire performance of heavy timber frame structures (e.g. post and beam structures) generally relies on the protection of the steel connectors. Additionally, encapsulation of steel connections with fire barriers is neither cost-effective nor efficient for construction, nor is it aesthetically pleasing. Therefore, Gerard et al. (2013) pointed out that there is a need for heavy timber connections that do not require fire barriers to achieve a good fire performance.

A comparatively low fire resistance is a general feature of traditional timber connections containing metal. The fire resistance (i.e. time to failure in a standard fire resistance test) of connections with exposed metallic parts exceeds $20 \mathrm{~min}$ only in exceptional cases (Carling, 1989). A fire resistance time as low as $5 \mathrm{~min}$ has been reported by Leicester et al. (1979) for toothed plate connections. Metallic parts conduct heat rapidly into connections, where the mechanical stresses are highest (Buchanan, 2002), and soften the wood. Hence non-metallic, inflammable connectors made out of materials with lower thermal diffusivity could enhance the fire resistance of connections in timber structures. This paper presents an alternative construction technique to the use of metallic connections in 'heavy timber' structures (e.g. post and beam structures and roof trusses) that does not require encapsulation or other passive fire protection.

Previous research has shown the potential use of alternative materials for replacing steel in timber connections. Drake et al. (1998) showed that glass-fibre-reinforced polymers (GFRPs) are suitable materials for shear dowels, and Thomson et al. (2010) proved that densified veneer wood (DVW) is a suitable flitch plate material. For this combination of materials, Thomson et al. showed that reduced fastener spacing and end distances can lead to connections of equal capacity to similar sized metallic connections. This type of connection is thus a viable alternative to traditional dowel-type connections. However, its fire resistance has not yet been adequately studied.

This paper presents an experimental study of the fire performance of a new type of timber connection with a DVW flitch plate and GFRP dowels (Figure 1). The influence of an intumescent layer intended to protect the flitch plate is also investigated.

Previous studies (Pedersen, 2002; Thomson et al., 2010) on non-metallic timber connections showed advantages regarding assembly and dimensional tolerances. Cutting the DVW flitch plate can be done using a timber saw and does not require pre-manufacturing (Pedersen, 2002). In contrast with metallic connections, the holes can easily be drilled in situ through

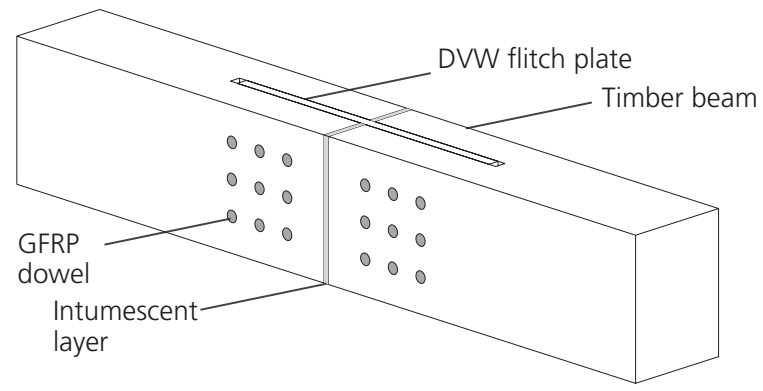

Figure 1. Non-metallic DVW flitch plate connection

the whole connection (including timber members and the flitch plate). Small hole clearances (i.e. the void between the fastener and the timber) can be achieved as the dowel can be positioned immediately after a hole is drilled through the constituents of the connections. This positively affects the initial stiffness of the connection (Leijten et al., 2006). Furthermore, due to the possibility of in situ assembly, the connection has high dimensional tolerance compared to connections that require prefabrication (Pedersen, 2002).

Brandon et al. (2013) showed that not every GFRP matrix would result in a fire-resistant dowel because some polymers soften at relatively low temperatures. Bank (2006) reported that phenolic resins have high glass transition temperatures (i.e. the temperature that indicates drastic reductions in mechanical properties) between 220 and $250^{\circ} \mathrm{C}$ and release water during combustion. Therefore, pultruded GFRP manufactured using phenolic resin is potentially advantageous for making timber connections with increased fire-resistance.

Carling (1989), Buchanan (2002) and Peng et al. (2010) have all presented overviews of the fire behaviour of timber connections. More recently, Frangi et al. (2010), and Palma et al. (2014) have presented experimental work on metallic mechanical timber connections in fire testing furnaces. The limited available research studies in this area have previously focused on the fire behaviour of conventional steel timber connections in standard (cellulosic) fires. However, non-standard fire tests (i.e. any fire test other than the standard fire resistance (furnace) test) at a small scale can often generate design and model input data for predictions of structural behaviour in real and standard fires (Bisby et al., 2013; Naughton et al., 2014; Östman and Tsantaridis, 1994). For instance, Moss et al. (2009) have presented a series of non-standard fire tests of metallic connections that led to conclusions similar to comparable studies using standard fire testing furnaces.

Standard fire tests performed in fire testing furnaces have been the basis of structural fire safety assessment for many decades 
(Bisby et al., 2013). At the turn of the twentieth century, Sachs (1903) presented a set of suggested standards for a fire resistance test which proposed the use of an essentially arbitrary 'fierce' fire represented by a minimum temperature from which the standard time-temperature curve followed in 1917. Fundamentally unchanged since its conception, the fire resistance test (i.e. furnace test) has raised the concern of numerous researchers and practitioners (e.g. Harmathy and Lie, 1970; Law et al., 2011). Harmathy and Lie (1970) stated that that the amount of energy (or fuel) necessary to perform a fire test is material dependent, and so it does not give a rational comparison between elements made of different materials (e.g. concrete, steel, timber). Gottfried et al. (2010) stated, based on a review of fire tests, that due to inhomogeneity the temperature differences generally are in the order of hundreds of degrees Celsius. They concluded that this could lead to a significant difference in time to failure than in the generally assumed homogeneous conditions. Consistency between furnaces at different laboratories also remains questionable, since the heat flux to which the specimens are subjected depends on the furnace lining materials and geometry, which varies among facilities (Law et al., 2011). Tests in which the heat flux can be controlled instead of the temperature avoid this problem. Additionally, the amount of energy exposed to specimens is not material dependent in heat-flux-controlled tests, allowing a more rational comparison between elements made of different materials than standard furnace tests. Furthermore, (nonstandard) tests have been developed that have an increased repeatability and (heat flux) homogeneity in comparison with the standard furnace test (Maluk, 2014).

Most of the current knowledge on the performance of structural timber in fire is based on tests carried out in standard furnace testing facilities, controlled to follow a standard time-temperature exposure (Östman et al., 2010). Rather than seeking the understanding of full-frame structural fire behaviour, the standard furnace test seeks to gauge the structural fire performance based on load-bearing capacity of an isolated structural element under a standard fire (i.e. time-temperature curve) (Bisby et al., 2013). This neglects the potential hazard given by real fire scenarios, not necessarily the standard fire. The lack of understanding of the behaviour of real buildings in real fires led to an increasing amount of non-standard fire tests (Bisby et al., 2013).

Within the scope of the work described here, smalland medium-scale specimens were tested by controlling the incident heat flux (i.e. imposed thermal energy dominated by radiation), or within an accurately controlled environmental chamber dominated by convection.

\section{Experimental study}

Three testing methodologies were used to determine the thermal characteristics and mechanical performance of non-metallic connections at high temperature. These are

- loaded tests in an environmental chamber

unloaded tests with constant incident heat flux

- unloaded tests with varying incident heat flux (to simulate a furnace test).

The materials used were consistent from test to test, with specimens consisting of

- Kerto-S laminated veneer lumber (LVL)

- Phenol F4010 reinforced with E-Glass G016X as a dowel material

- non-impregnated cross-laminated DVW with an average density of $1308 \mathrm{~kg} / \mathrm{m}^{3}$ as a flitch plate material

- black mild steel (only in metallic dowelled specimens).

The dimensions and configurations of the tested specimens are defined in the following sections. All specimens were conditioned at $60 \%$ relative humidity for at least 2 months prior to testing.

\subsection{Mechanical tests in an environmental chamber}

Figure 2 shows the test setup of tensile tests of two single dowelled flitch plate connections that were performed in an environmental chamber. The ports at the top and bottom of the environmental chamber were sealed with insulation boards prior to testing. Optical assessment of the specimens and their failure modes was performed through a small window in the door of the environmental chamber. A $25 \mathrm{~mm}$ thick ceramic fibre board was positioned at the top and bottom of the specimen to reduce the heat flow through the specimen ends, replicating the real thermal boundary condition. The fibre board replaces the opposing beam in a splice connection. If the heat flow through the ceramic board is close to zero, it functions as a symmetry plane, which is present in a real splice connection. Aluminium foil and two layers of ceramic paper were used to protect the flitch plate from breaking inside the two loading ports of the chamber.

Mechanically loaded tests were performed in the environmental chamber at temperatures up to $610^{\circ} \mathrm{C}$, which was the maximum possible temperature attained by the environmental chamber. Timber chars at approximately $300^{\circ} \mathrm{C}$ (Buchanan, 2002) and phenolic resins have glass transition temperatures ranging from 220 to $250^{\circ} \mathrm{C}$ (Bank, 2006), hence decomposition (or softening) of the constituents in a non-metallic timber connection are expected to occur at temperatures well below $610^{\circ} \mathrm{C}$. Therefore, temperatures of $610^{\circ} \mathrm{C}$ are sufficient to achieve failure of the test specimens. Tests of metallic and nonmetallic connections were performed under sustained tensile loads of 20 and $40 \%$ of the experimentally determined capacity of the connection at ambient temperature. The loads were 
Fire performance of metal-free timber

connections

Brandon, Maluk, Ansell et al.

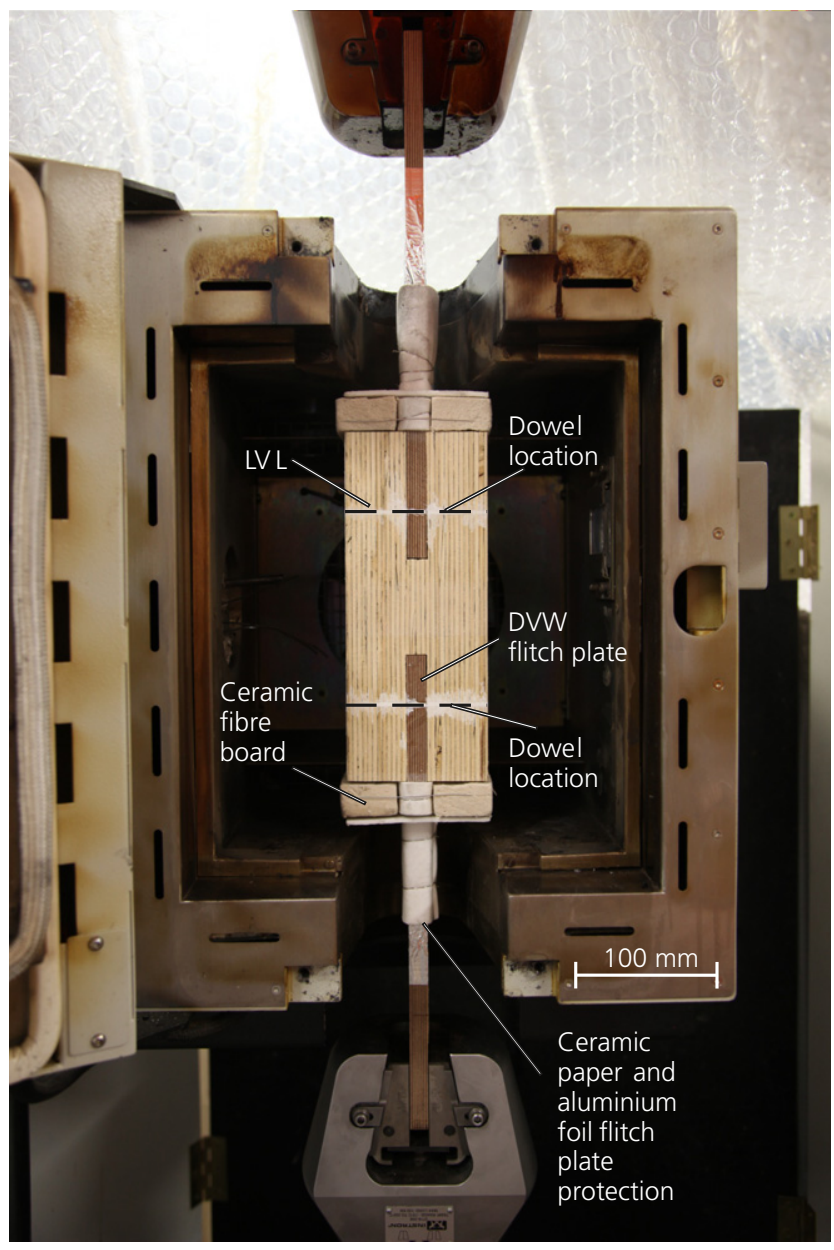

Figure 2. Setup of tensile connection test in an environmental chamber

applied at a constant rate, according to timber test standards (BSI, 1991), so that the required load was reached within $2 \mathrm{~min}$ and the heating sequence commenced $140 \mathrm{~s}$ after the initiation of the load at a rate of $15^{\circ} \mathrm{C} / \mathrm{min}$ until a temperature of $610^{\circ} \mathrm{C}$ was reached or failure of the specimen was observed. The test specimens contained two flitch plate connections, and the load was applied outside the chamber (Figure 2). Both metallic and non-metallic connections were tested in order to compare their behaviour and failure modes at elevated temperatures.

Table 1 gives an overview of the tests that were carried out in the environmental chamber. The specimen dimensions of the different test series, namely FA, FB, FC and FD, are shown in Figure 3. Test series FB has similar specimen dimensions to FA and was designed for a comparative study between nonmetallic and metallic connections at elevated temperatures. A reduced end distance of $50 \mathrm{~mm}$ was adopted for non-metallic dowels, in agreement with the recommendations of Thomson et al. (2010). Test series FC had a minimum edge distance chosen in accordance with Eurocode 5 (BSI, 2004). In series FA, the shortest distance from the surface to the shear plane of the dowel was along the dowel, which was not the case in test series FC. The most significant direction of heat transfer was therefore expected to be different for these series of tests. All unloaded tests were performed on specimens instrumented with 12 thermocouples located at various depths from the specimens' exposed surfaces, as shown in Figure 3. Furthermore, Table 1 shows the average ambient capacity, determined from the ambient strength of four control specimens tested for each type of specimen.

\subsection{Tests with constant incident heat flux}

The influence of differences in thermal properties of LVL, GFRP and DVW on heat transfer was studied using a standard cone calorimeter (BSI, 2002). Specimens containing one (e.g. LVL) or more (e.g. LVL plus dowel) of the relevant materials were subjected to a constant incident heat flux of $50 \mathrm{~kW} / \mathrm{m}^{2}$ (Figure 4). Thermocouples were located at different depths in the specimens to measure the thermal gradients during the tests.

\begin{tabular}{llccrc}
\hline $\begin{array}{l}\text { Test } \\
\text { series }\end{array}$ & Description & $\begin{array}{c}\text { Number of tests } \\
\text { loaded at 40\% of } \\
\text { the ambient capacity }\end{array}$ & $\begin{array}{c}\text { Number of tests } \\
\text { loaded at 20\% of } \\
\text { the ambient capacity }\end{array}$ & $\begin{array}{c}\text { Number of tests } \\
\text { without mechanical } \\
\text { load (i.e. 0\%) }\end{array}$ & $\begin{array}{c}\text { Average ambient } \\
\text { capacity, determined } \\
\text { from four samples: kN }\end{array}$ \\
\hline FA & Non-metallic connection & 3 & 3 & 1 & $9 \cdot 2$ \\
FB & Metallic connection & 1 & 1 & 1 & $21 \cdot 9$ \\
FC & $\begin{array}{l}\text { Non-metallic connection with } \\
\text { minimum edge distance }\end{array}$ & 2 & 3 & 1 & $9 \cdot 2$ \\
FD & $\begin{array}{l}\text { Non-metallic connection } \\
\text { loaded perpendicular to the }\end{array}$ & 2 & 3 & 1 & $3 \cdot 8$ \\
& grain
\end{tabular}

Table 1. Overview of loaded tests in environmental chamber 


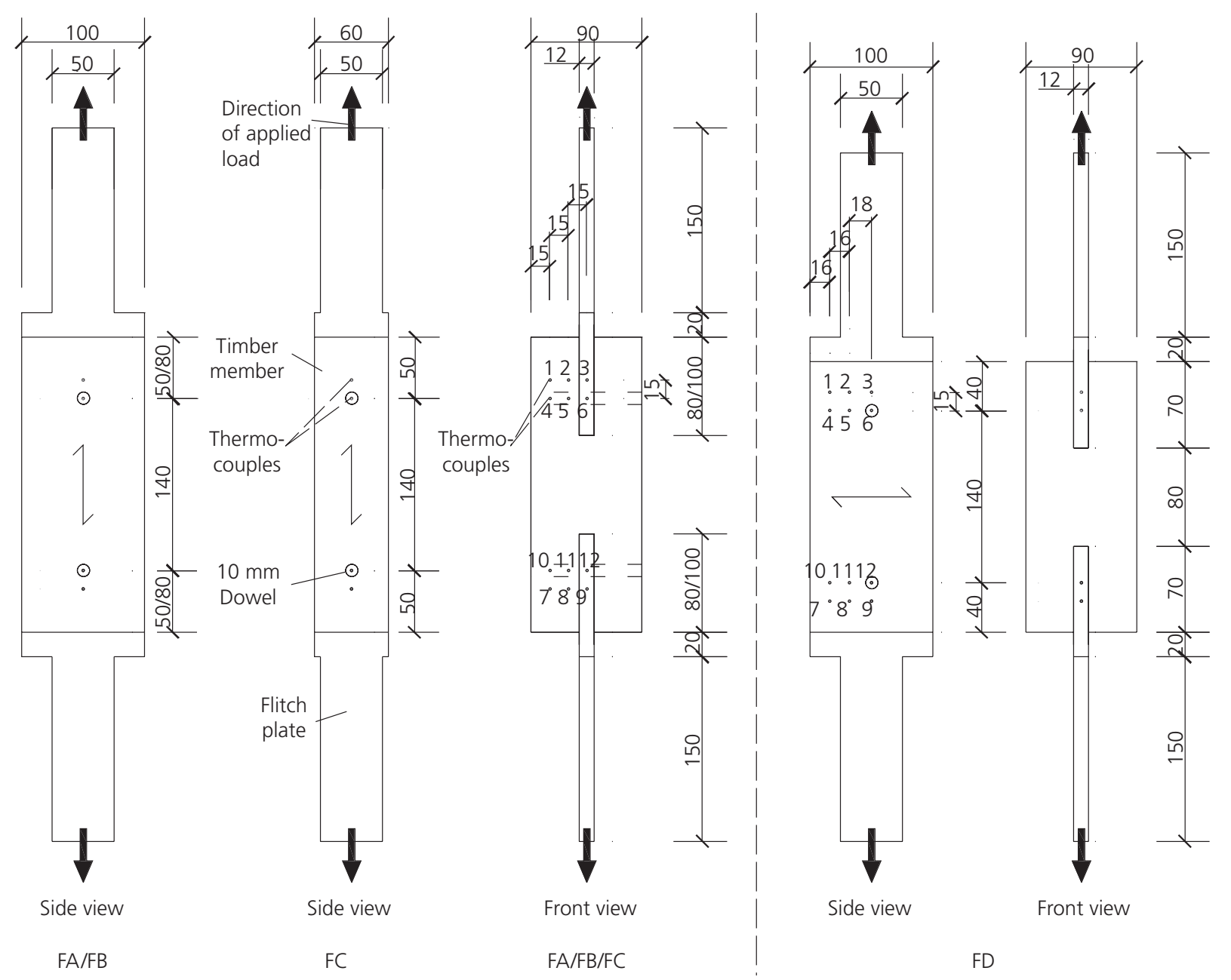

Figure 3. Dimensions of mechanically loaded specimens and locations of thermocouples (dimensions in $\mathrm{mm}$ )

The cone calorimeter is designed to expose small samples to a homogeneous heat flux over its surface and allows the study of pseudo one-dimensional heat transfer in the sample under carefully controlled conditions. However, the heat flow in the sample can never be perfectly one-dimensional, as heat losses through the non-exposed sides of the specimen will always occur. A layer of aluminium foil and two layers of $3 \mathrm{~mm}$ ceramic paper were used as boundary conditions to limit heat losses through the sides of the samples. By limiting heat flow in horizontal directions, almost one-dimensional heat flow can be achieved. The effectiveness of the boundary conditions was evaluated using the test data.

Four test series, namely CA, CB, CC and CD, were performed to study the in-depth temperature evolution of the different connection materials used in this study. The specimen dimensions and thermocouple positions are shown in Figure 5. Test series CA aimed to confirm that the heat was evenly distributed and the heat losses through the sides were insignificant. Test series CB aimed to show the influence of a GFRP dowel on the heat transfer in LVL. As previously discussed, the flitch plate in the gap between two opposing beams can be protected using an intumescent layer (Figure 1). The effectiveness of this layer was studied using series CC. Finally, series $\mathrm{CD}$ allowed a comparative study of the heat transfer through LVL and the in-plane heat transfer through DVW sheets. All specimens were tested in triplicate, with the exception of series $\mathrm{CD}$, which had only one specimen.

\subsection{Tests with varying incident heat flux}

The heat-transfer rate inducing system (H-TRIS) is a novel testing system developed at the University of Edinburgh 
(Maluk, 2014) in which the position of an array of high intensity propane-fired radiant heat panels is actively controlled (Figure 6) in order to vary the time history of the incident heat flux imposed on medium-scale test specimens. Although similar techniques have been widely used within the fire science community, this novel approach resulted from a change in attitude towards controlling thermal exposure not by temperature, as in standard fire resistance tests in furnaces, but rather by incident heat flux. In contrast with standard furnace tests, which are expensive, time-consuming and suffer from numerous inherent problems (e.g. low repeatability and homogeneity), H-TRIS tests are inexpensive and highly repeatable (Maluk, 2014).

The set of H-TRIS tests was performed with the aim of determining the influence of the non-metallic dowels, flitch plate and intumescent layer on the thermal response of timber connections in fire. The samples consisted of full flitch plate connections. Fifteen thermocouples measured temperatures at different positions at different depths within the connections. Four H-TRIS tests of $60 \mathrm{~min}$ duration were performed using a simulated standard fire exposure. The positions of the

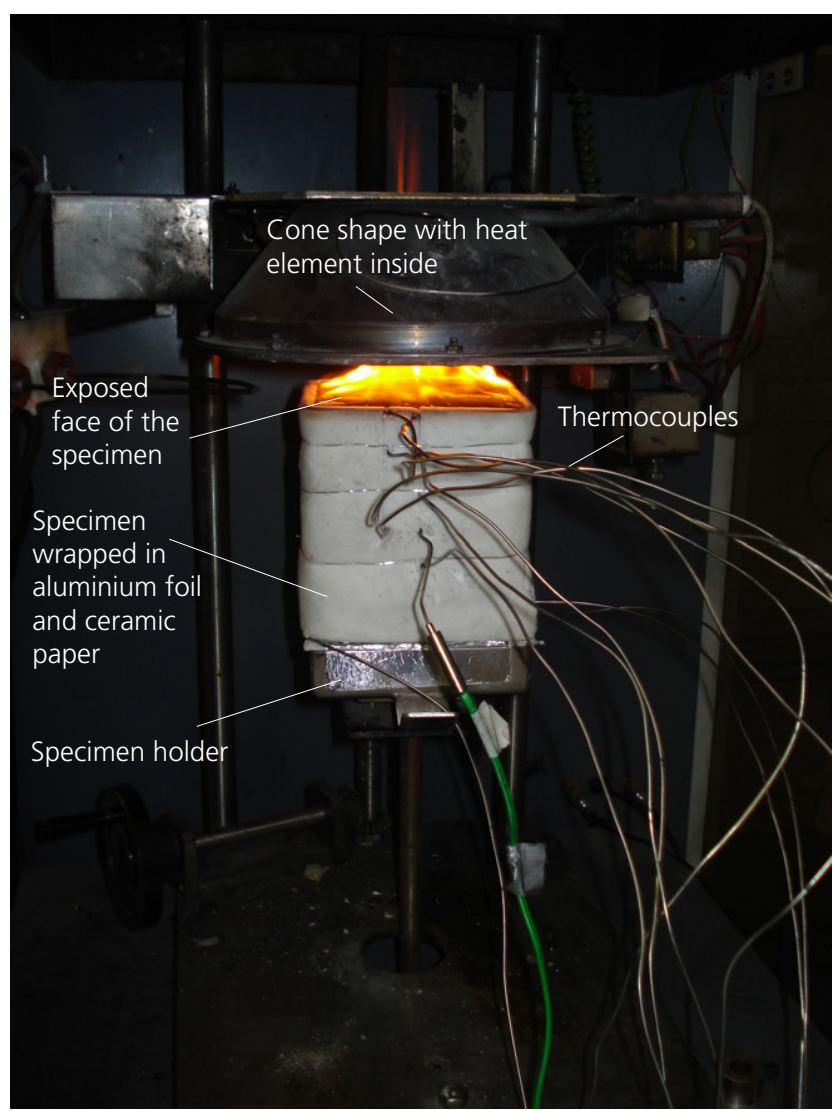

Figure 4. Cone calorimeter test thermocouples are shown in Figure 7. Two of the specimens contained an intumescent layer to protect the flitch plate. Additionally, two similar specimens were tested without the intumescent protection. The applied incident heat flux curve (shown in Figure 8) was defined based on the outcomes of a previous study (Maluk, 2014) aimed at replicating the thermal exposure experienced by concrete specimens during standard fire resistance furnace tests controlled to follow the standard time-temperature curve (BSI, 2012).

Furthermore, in this test it was important that heat losses or gains from the non-exposed sides were limited. Aluminium foil was tightly wrapped around the sides of the specimen. The specimen was surrounded by $25 \mathrm{~mm}$-thick ceramic fibre board (Figure 6). This board was also used to protect the sample holder.

\section{Results and analysis}

\subsection{Loaded tests in the environmental chamber}

The time-history of the crosshead displacements of test series FA and FB are shown in Figure 9, in which the black and grey curves represent the non-metallic and metallic connections, respectively. The four different failure modes that occurred are denoted in the legend. Embedment failure occurred in both metallic dowel specimens. The failure mode that occurred in the non-metallic dowel specimens at a $20 \%$ load level was flitch plate failure (this occurred in the locations shown in Figure 10). At the higher load level, shear plug failure was the general mode of failure. The failure mode represented by the square point in Figure 9 is deemed as invalid given that the failure in the slender part of the flitch plate was due to lack of protection from the aluminium foil and ceramic paper, rather than in the connection. It can be seen that the non-metallic connections had a longer time to failure $(54$ and $66 \mathrm{~min}$ on average for 40 and $20 \%$ load levels, respectively) than the metallic connections. This is more significant for connections with a $20 \%$ load level.

Figure 11 shows the crosshead movement during the test for series FC. Clear similarities can be seen with the results of series FA. However, the time to failure was more than $10 \mathrm{~min}$ less. Specimens in series FC contained a minimum edge distance of $30 \mathrm{~mm}$, which allowed more rapid heat transfer to the dowel than series FA.

The connections loaded at $20 \%$ showed flitch plate failure, similar to series FA. The connections with $40 \%$ load showed embedment failure and shear plug failure. Shear failure of the dowel was also observed in one shear plane.

Results of test series FD are shown in Figure 12. All specimens showed tensile failure perpendicular to the grain, and the time to failure was less than the parallel-to-grain specimens of series 

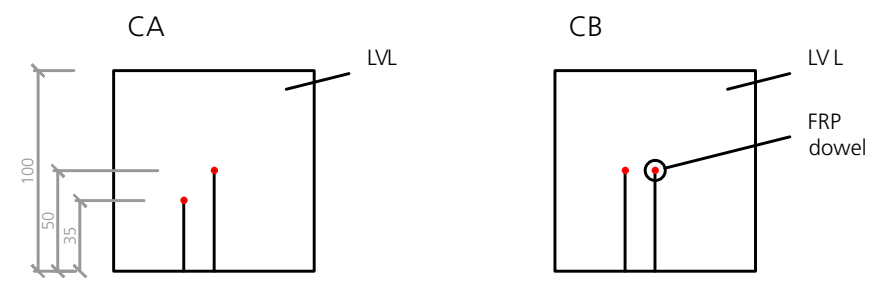

Top view
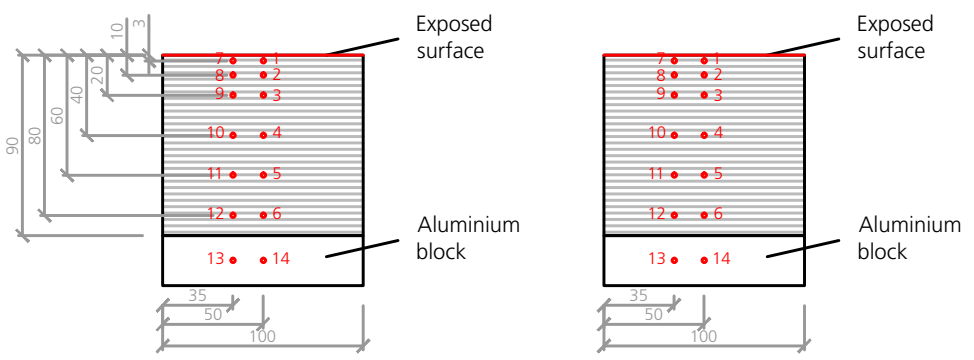

Front view
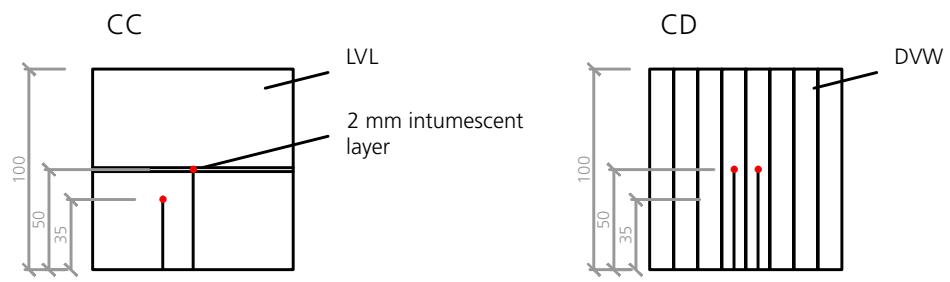

Top view
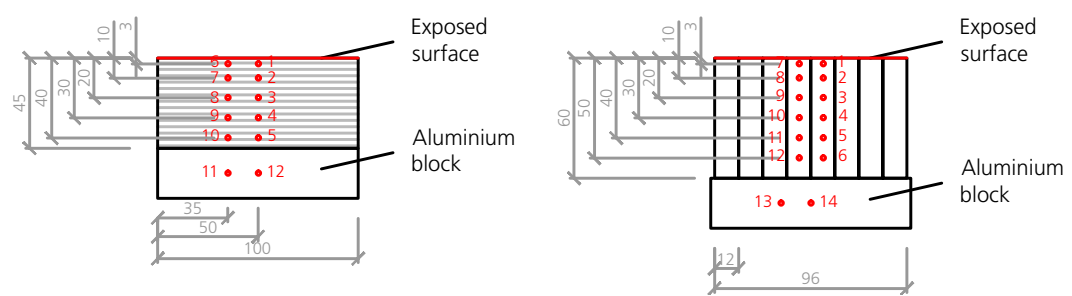

Front view

Figure 5. Location of thermocouples in constant heat flux tests

(dimensions in $\mathrm{mm}$ )

FA. Specimens of series FA and FD had similar cross sections and load levels. The main difference was the load grain angle, which must have caused the lower time to failure. The tests conducted in the environmental chamber led to consistent results with a few notable exceptions. For instance, one test at $20 \%$ load showed a relatively short time to failure. This specific test displayed excessive deformation during the loading phase (Figure 12). Despite the high predictability of the LVL used in the current study, an imperfection or an initial crack in the timber near the dowel could cause premature failure. However, it can be argued that the mechanical properties of timber perpendicular to the grain are more variable than parallel to the grain (FPL, 2010).

Measured temperatures after $50 \mathrm{~min}$ of heating in tests without mechanical load are shown in Table 2. The names indicate the test series and the load level (FA0\%, FB $0 \%, F C 0 \%$ and $\mathrm{FD} 0 \%$ ). The averages of thermocouples that were located in the same material and the same depth are shown (e.g. the average temperature measured by TC 2 and TC 8 in test FA $0 \%$ was $134^{\circ} \mathrm{C}$ ). Temperatures shown in bold text were located in the dowel. It can be seen that the temperature range in the steel dowel was significantly smaller than the temperature range in the GFRP dowels, showing that the heat was conducted more rapidly along the steel dowel.

As mentioned before, the specimens of series FA and FB had similar dimensions. However, the measured temperatures at 30 and $45 \mathrm{~mm}$ from the exposed surface were significantly lower in the non-metallic connections, which confirmed that considerably less heat was transferred into the non-metallic connections. Longitudinal sections of the non-metallic specimen 


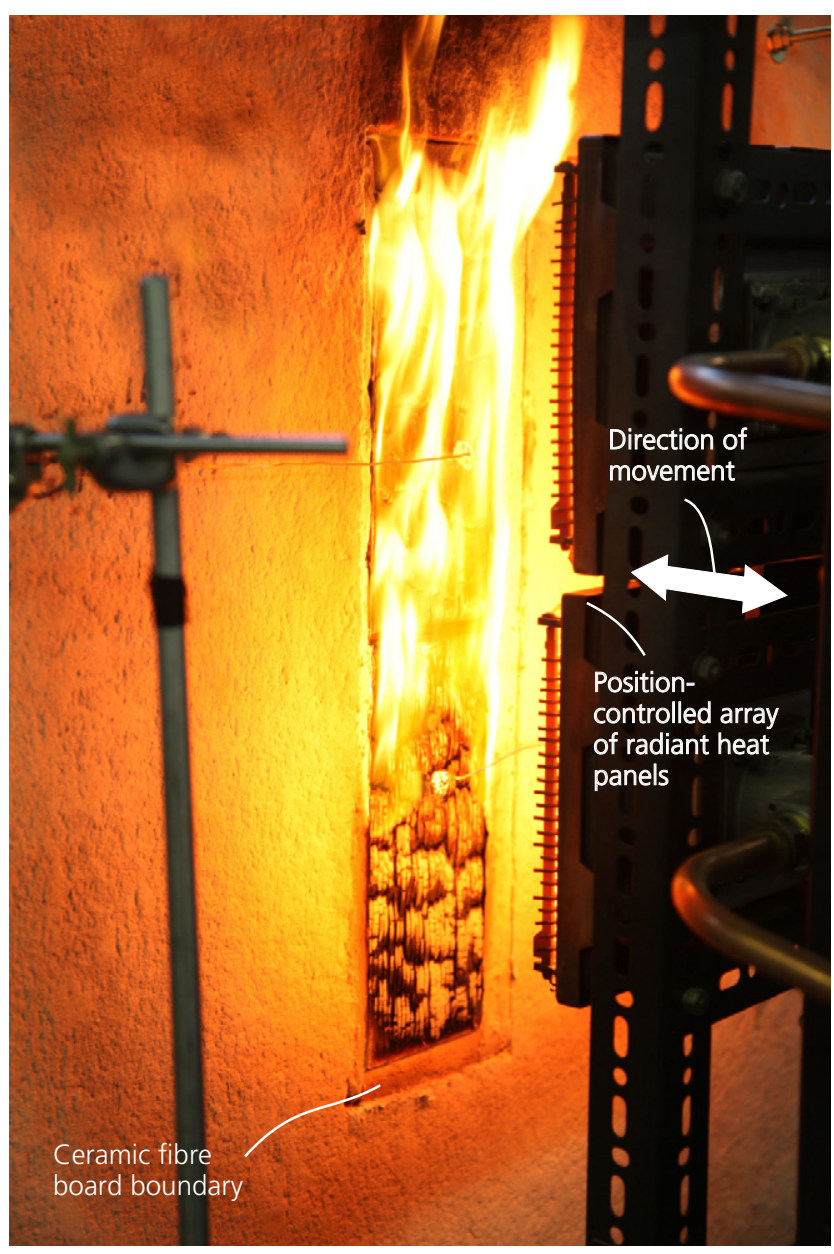

Figure 6. H-TRIS fire test apparatus Mk I (Maluk, 2014)

FA0 $\%$ and metallic specimen FD0 $\%$ (Figure 13) show important differences in charring behaviour. The non-metallic connection (Figure 13(a)) had a clear char layer that was not visibly influenced by the presence of the dowel. This suggests that the heat transfer would be similar in a solid timber block. Heat transfer along the dowel thus appears to be governed by the timber. Figure 13b shows that the timber charred deeper into the connection. The most significant difference can be seen in the surface of the dowel hole. The timber adjacent to the dowel is fully charred in the case of the metallic connection (Figure 13(b)); this is also the location where the timber stresses are highest, which correlates well to the embedment failures that occurred in the mechanically loaded steel dowel specimens.

\subsection{Tests with constant incident heat flux}

Average test results of the three specimens of series CA are shown in Figure 14, in which curves with similar line types

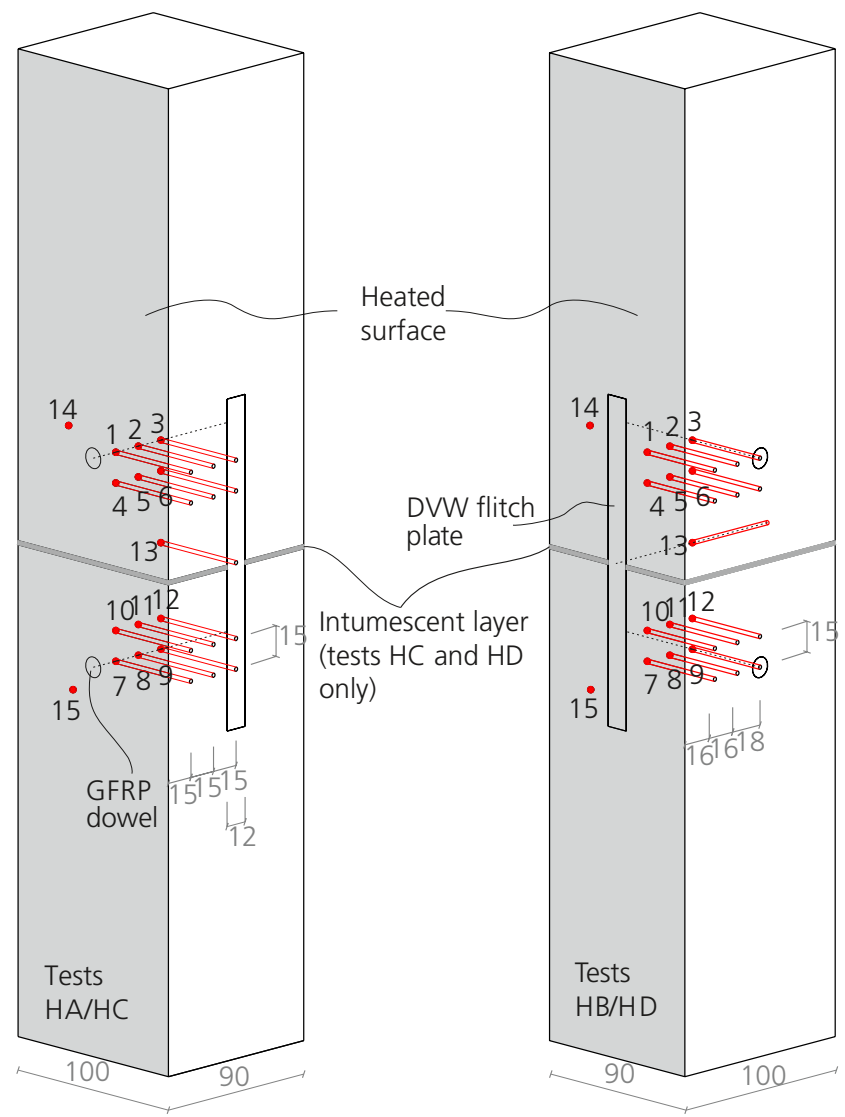

Figure 7. Locations of thermocouples in H-TRIS tests (dimensions in $\mathrm{mm}$ )

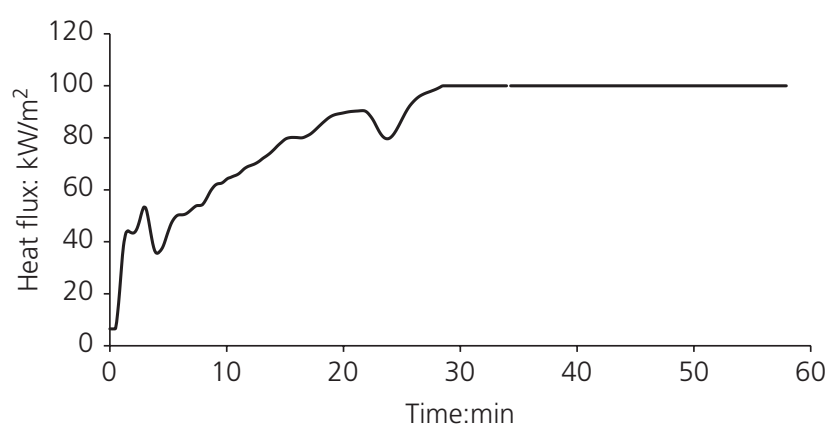

Figure 8. Time-history of incident heat flux imposed using H-TRIS

represent similar distances from the exposed surface. Thermocouples near the exposed surface became loose when the timber burned away and were removed after they lost fixed positions; hence, the discontinuous curves of TC1 and TC7. No significant differences were seen between the central line of thermocouples (TC1 to TC6) and the eccentric line of 


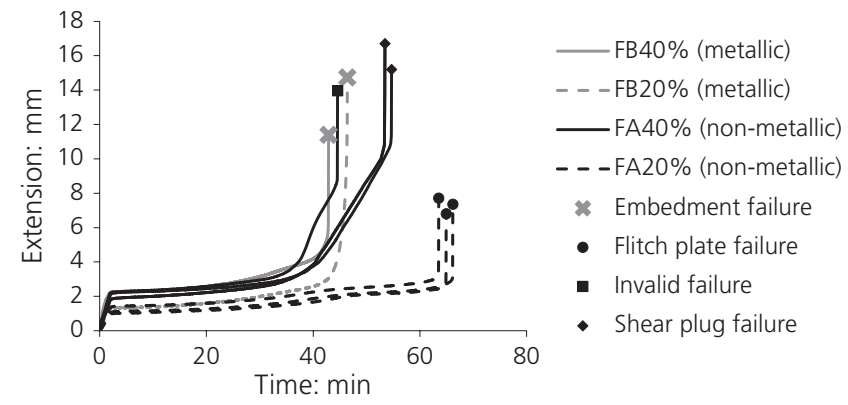

Figure 9. Crosshead displacement plotted against time of test for series FA and FB

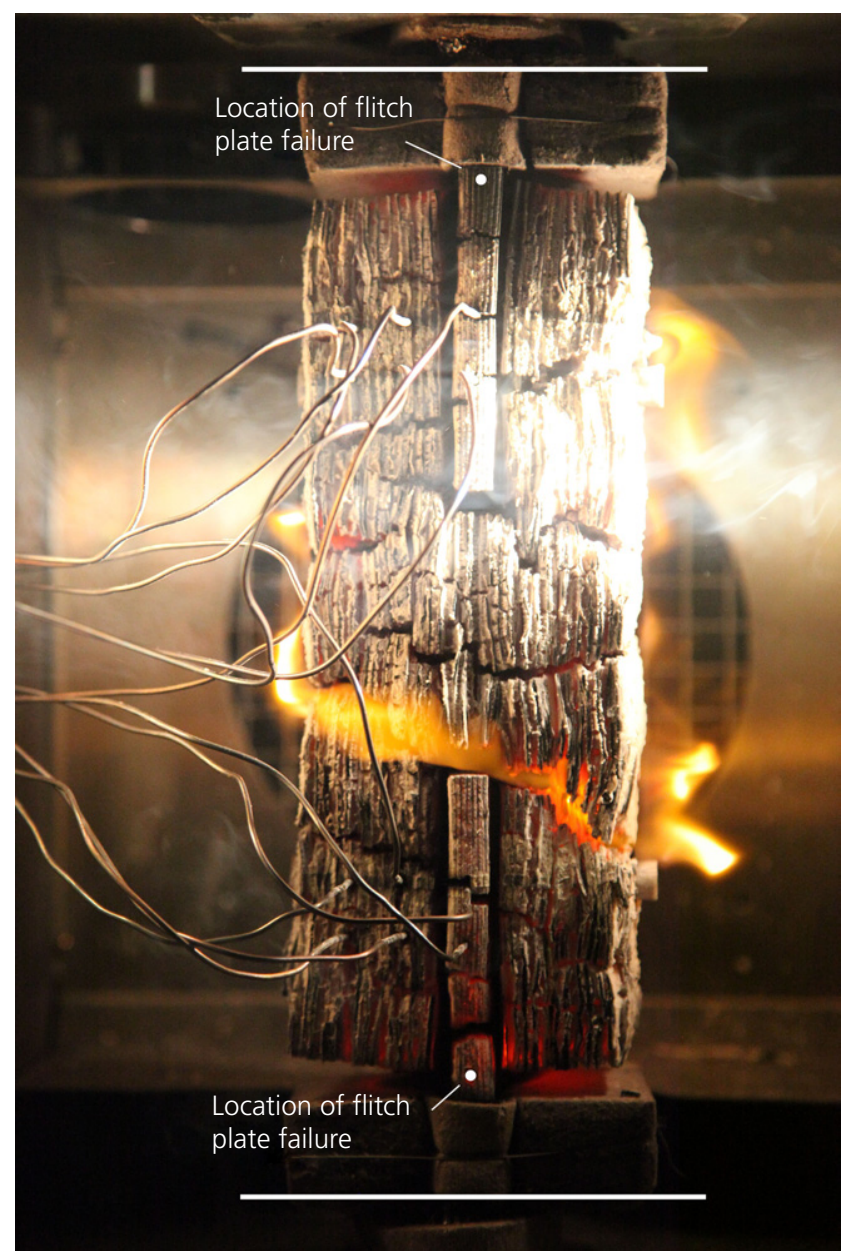

Figure 10. Specimen of series FA after 50 min of heating

thermocouples (TC7 to TC12). This indicates that the heat flux to the surface was homogeneous and also that heat losses or gains from the samples' sides were sufficiently small that

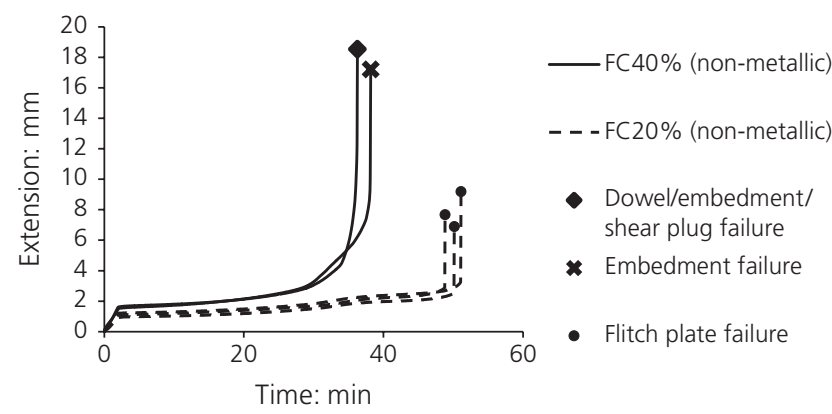

Figure 11. Crosshead displacement plotted against time of test for series FC

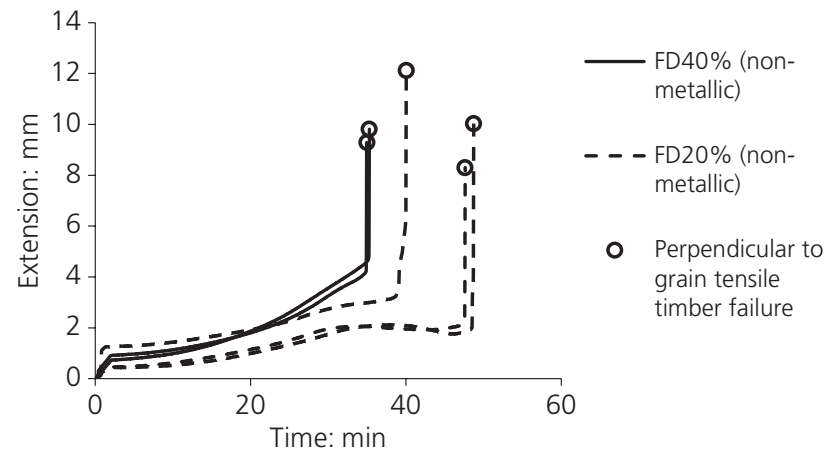

Figure 12. Crosshead displacement plotted against time of test for series FD

one-dimensional heat flow was maintained in the area around the thermocouples. Figure 15 shows a section of a typical specimen after an hour of heating. The char depth is constant and is not visibly different on the sides of the specimen. This confirms the homogeneity of the thermal exposure and boundary conditions. Neither temperature measurements deeper than $20 \mathrm{~mm}$ showed an influence of the cracks, which suggests that the influence of surface cracks on the heat transfer was small or even negligible.

Figure 16 shows average results of test series $\mathrm{CB}$ and shows temperature evolutions very similar to those shown previously in Figure 14. Curves with the same line type represent temperature measurements at the same depth. The black and grey curves show temperatures inside the dowel and LVL, respectively. No obvious temperature differences between the dowel and the LVL or flitch plate were seen. This again indicates that the heat flow was mainly one dimensional. However, it is unlikely that the heat transfer properties of GFRP are identical to those of LVL, resulting in three-dimensional heat flow. The similarity of results of series $\mathrm{CA}$ and $\mathrm{CB}$ indicate that the 


\begin{tabular}{|c|c|c|c|c|c|c|}
\hline & \multicolumn{4}{|c|}{ Average temperatures: ${ }^{\circ} \mathrm{C}$} & \multirow[b]{2}{*}{ TC depth: $\mathrm{mm}$} & \multirow[b]{2}{*}{ Material } \\
\hline & FA0\% & FBO\% & FCO $\%$ & FD0\% & & \\
\hline TC 1 and TC 7 & 356 & 391 & 559 & 354 & \multirow[b]{2}{*}{15} & LVL \\
\hline TC 4 and TC 10 & 306 & 377 & 501 & 302 & & GFRP/steel (dowel) \\
\hline TC 2 and TC 8 & 134 & 242 & 413 & 231 & \multirow[b]{2}{*}{30} & LVL \\
\hline TC 5 and TC 11 & 104 & 310 & 354 & 173 & & GFRP/steel (dowel) \\
\hline TC 3 and TC 9 & 106 & 328 & 264 & 216 & \multirow{3}{*}{45} & DVW/steel (flitch plate) \\
\hline TC 6 and TC 12 & 102 & 343 & 281 & 146 & & GFRP/steel (dowel) \\
\hline Average temperature range in dowel: ${ }^{\circ} \mathrm{C}$ & 204 & 67 & 220 & 156 & & \\
\hline
\end{tabular}

Temperatures shown in bold were located in the dowel.

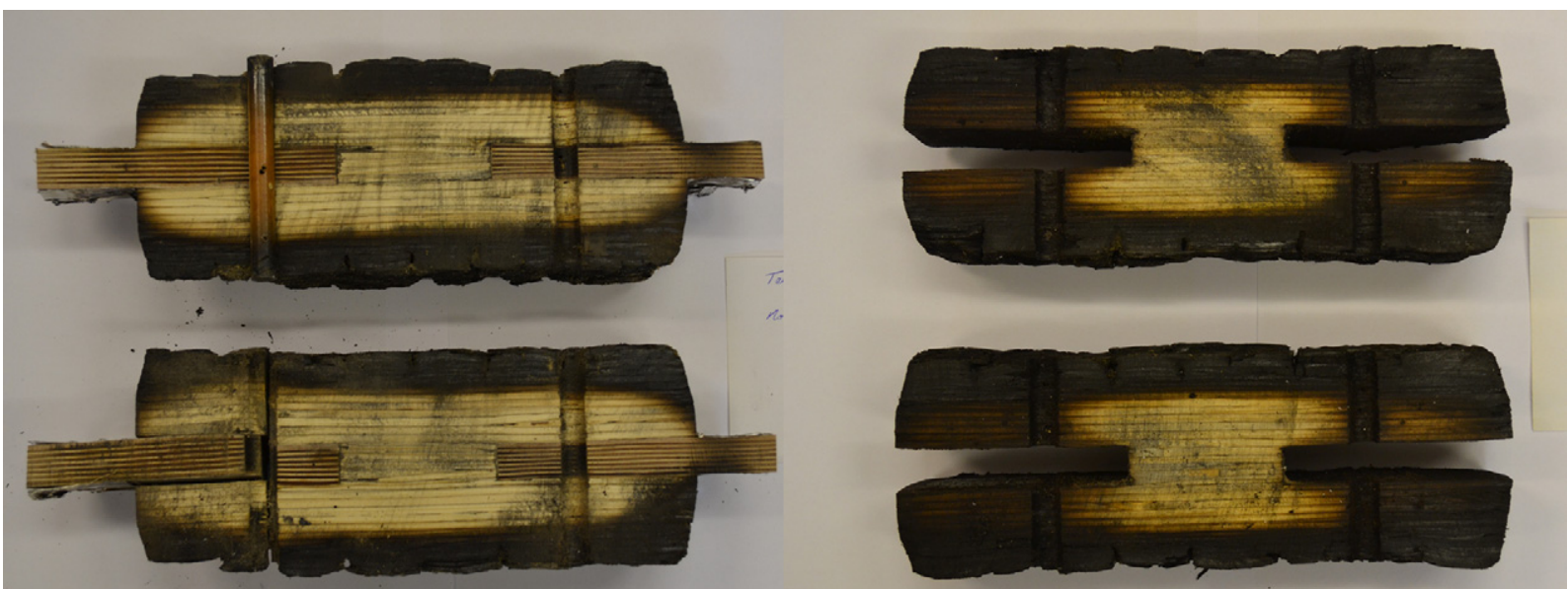

(a)

Figure 13. Longitudinal section of typical (a) non-metallic and (b) metallic connections after 50 min of heating

timber governed the heat transfer and that the dowel was heated rapidly by the surrounding LVL. Figure 15 shows a section of the specimen after $60 \mathrm{~min}$ of heating. It can be seen that the charring depth is again constant. This confirms that the heat transfer was not obviously influenced by the dowel, but was governed by the LVL.

From the results of the mechanically loaded tests it appeared that the flitch plate of the connection may fail first in a fire. Series CC aimed to study the effectiveness of intumescent sealing between two LVL members. From the results shown in Figure 17 it is clear that the temperatures measured in the LVL (grey) were not always similar to the measurements in the intumescent sealing. To show that this was not just caused by variability in

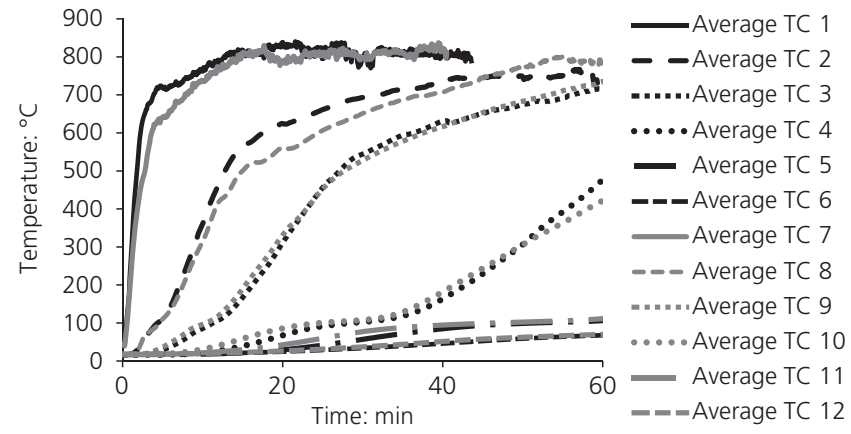

Figure 14. Average temperature results of test series CA 


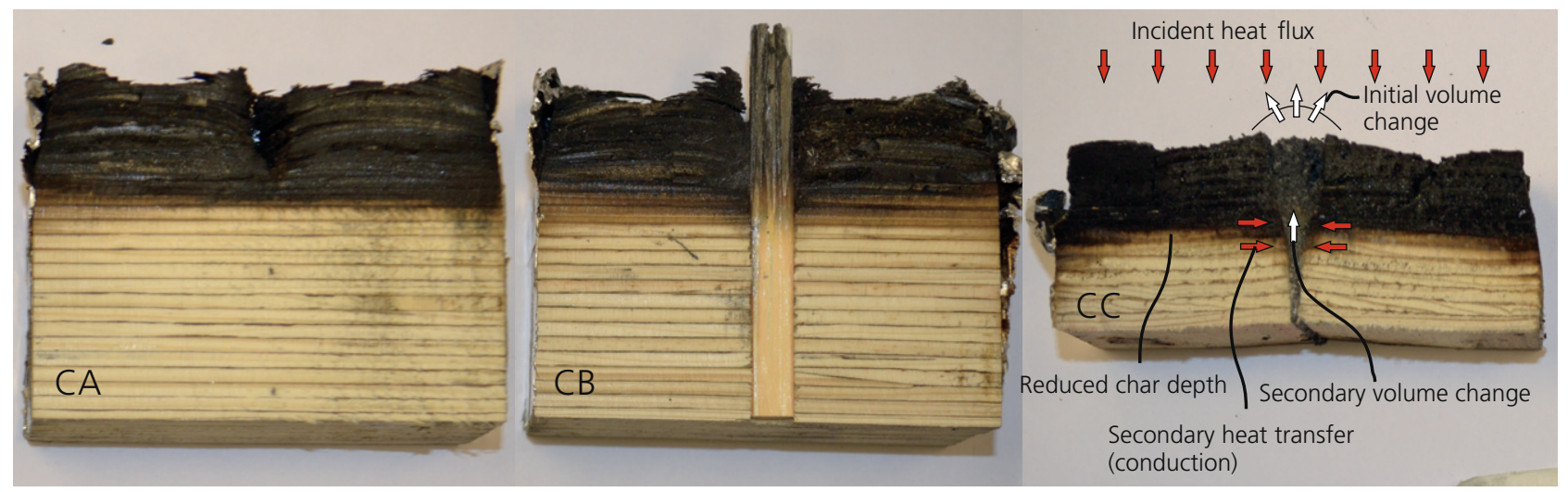

Figure 15. Section of specimens of series $C A, C B$ and $C C$ after testing

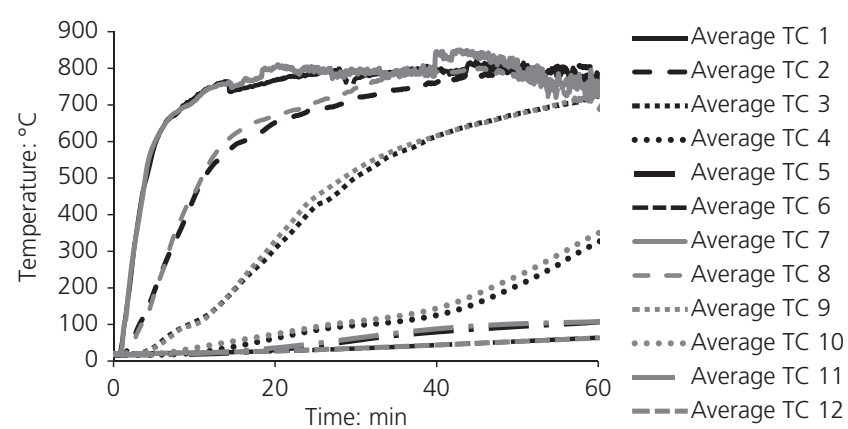

Figure 16. Average temperature results of test series CB

test results all data are shown rather than only the averages. Near the surface, the LVL seems to heat up faster than the intumescent layer whereas at a depth of $30 \mathrm{~mm}$ (TC4 and TC9) the intumescent layer heats up faster than the timber. The temperatures in the two materials were approximately similar at $20 \mathrm{~mm}$ depth during the tests. The higher efficiency of the intumescent sealing near the surface can be explained by noting the direction of expansion of the intumescence. Figure 15 shows the char layer after $25 \mathrm{~min}$ of testing and schematically shows the direction of the heat flow and expansion. Near the surface, the intumescent layer rapidly expanded in the direction of the heat source, decreasing the thermal conductivity and increasing the volume. The LVL at this location heated up faster than the intumescent layer, resulting in heat flow by conduction from the LVL to the intumescent layer. This conduction also led to expansion of the intumescent layer; however, it did not lead to a volume increase in the direction of the heat source. Thus, the intumescent layer deeper in the sample was less effective. Solid insulating materials such as ceramic paper could also be considered as protection of the flitch plate in future work; however, an advantage of an

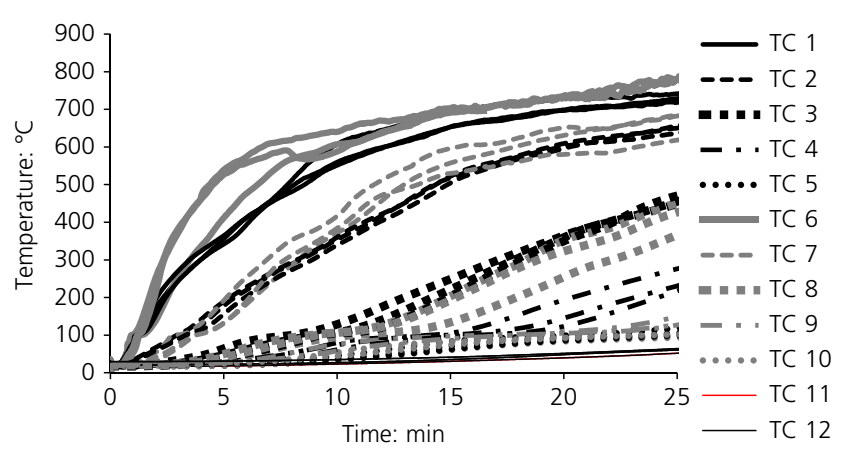

Figure 17. Temperature results of test series CC

intumescent layer is that it fills the void that comes to exist when the timber around the gap shrinks during heating.

Test results of series $\mathrm{CD}$ are given along with the results of series CA to compare heat transfer through the LVL and DVW in Figure 18. Both materials showed a reduction of heating rate at $100^{\circ} \mathrm{C}$ due to the energy required to evaporate moisture. At temperatures above $100^{\circ} \mathrm{C}$ the materials show a clear difference in heating rate. This is likely due to the difference in dry density and therefore the difference in heat capacity (for temperatures over $100^{\circ} \mathrm{C}$ ). The DVW showed a lower heating rate in general and a reduction of heating rate at temperatures close to $300^{\circ} \mathrm{C}$. According to Frangi (2001) the latter is caused by pyrolysis, which generally takes place in timber at temperatures around $300^{\circ} \mathrm{C}$.

\subsection{Tests with varying incident heat flux}

Figures 19-22 show the H-TRIS test results. The grey curves give the temperatures of thermocouples in the lower 


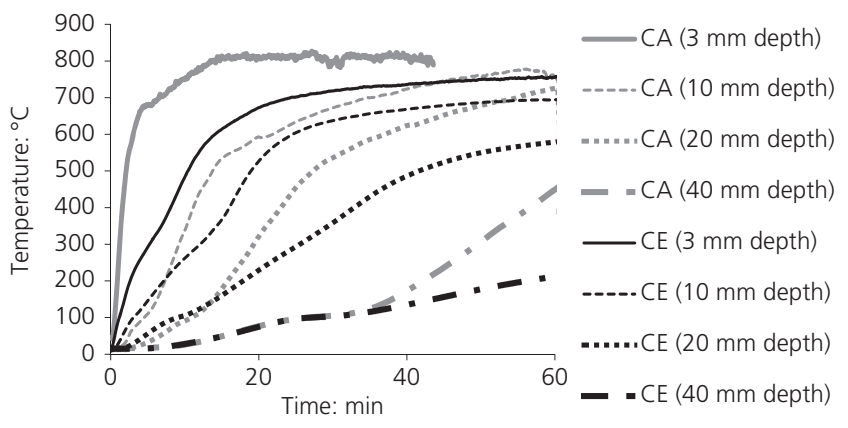

Figure 18. Average temperature results of test series $C A$ and $C D$

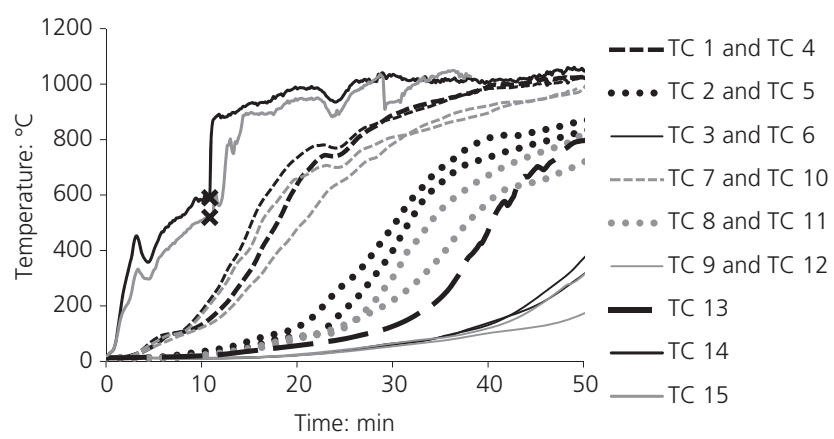

Figure 19. Temperature results of H-TRIS test HA

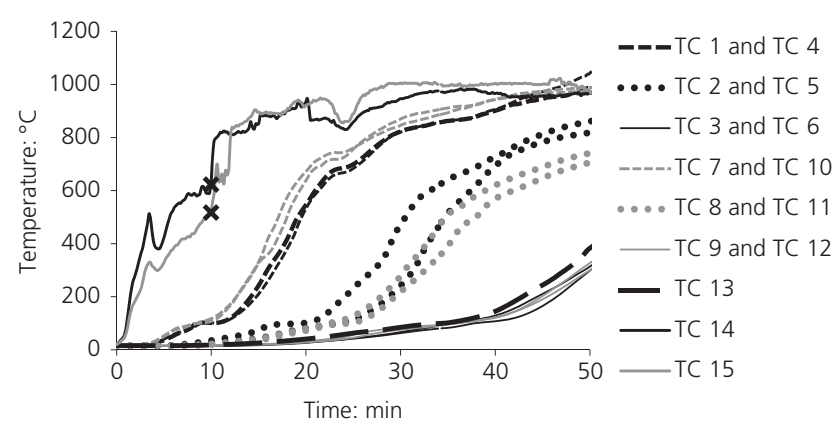

Figure 20. Temperature results of H-TRIS test HC

symmetrical half of the sample and the black curves show the temperatures of the upper half.

Specimens HB and HD had thermocouples located in the flitch plate or the dowel. The results of these tests show significantly less scatter than the results of tests $\mathrm{HA}$ and $\mathrm{HC}$ in which many thermocouples were located in the LVL. This indicates that DVW has more consistent heat transfer properties

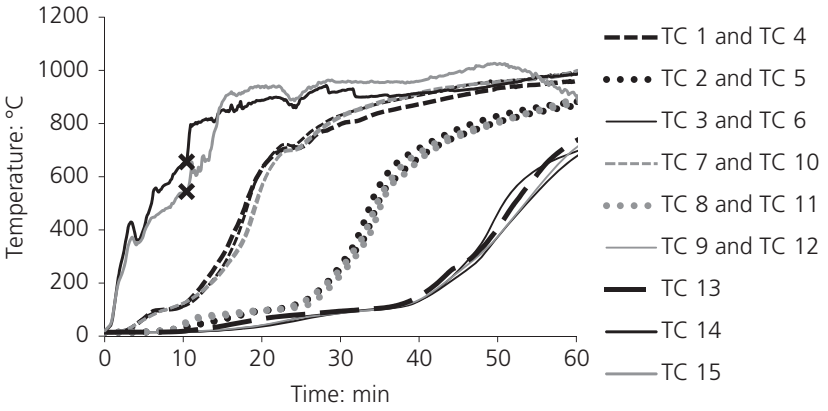

Figure 21. Temperature results of H-TRIS test HB

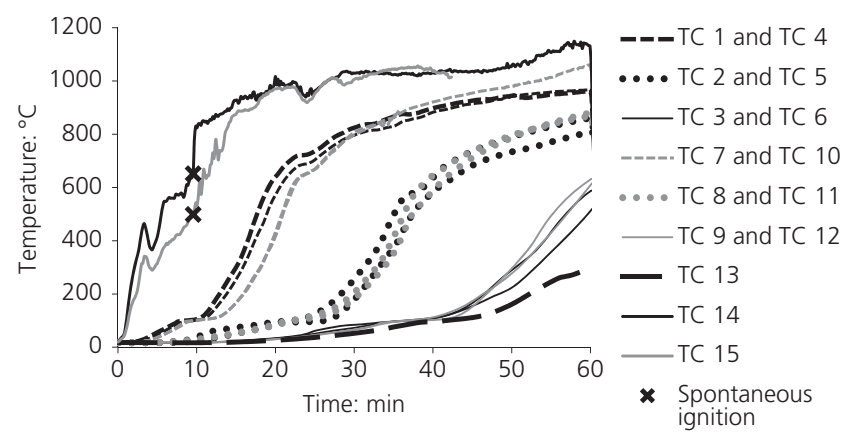

Figure 22. Temperature results of $\mathrm{H}$-TRIS test HD

than LVL. It also means that results of $\mathrm{HB}$ and $\mathrm{HD}$ give better insights into the performance of the H-TRIS testing methodology.

Measurements from TC 14 and 15 were taken at the surface and were influenced by direct radiation and convection; these only gave an approximation of the surface temperature. The measurements of TC 14 at the upper half of the connection were higher than the measurements of TC 15 at the lower half during the first $12 \mathrm{~min}$ of all tests. This is because free convection caused more convective heat losses at the bottom.

TC 13 measured the temperature in the centre of the flitch plate in all tests. The differences in measurements from TC 13 in tests $\mathrm{HA}$ and $\mathrm{HC}$ are clear. The intumescent layer in test HC protected the flitch plate so that the temperatures only just exceeded temperatures measured at the same depth in the connection. In test series $\mathrm{HB}$ and $\mathrm{HC}$ the same effect can be seen; from this side the protection was not in line with the heat source and the flitch plate. Nevertheless, the flitch plate was colder in the test with intumescent protection, suggesting heat was conducted from the flitch plate to the intumescent layer. 
The measured temperatures from the different tests show no obvious differences. Furthermore, no clear difference was found between the temperatures in the LVL members and those in the dowels. As there was considerably more LVL than GFRP or DVW, this suggests that the heat transfer was governed by the timber.

\section{Conclusions}

This study has shown the results and analysis of experimental work on the fire performance of non-metallic connections used in heavy timber structures. As shown herein, DVW flitch plate and fibre-reinforced phenolic dowel connections may be designed to perform appropriately during fire, without cost or aesthetic constraints given by the use of passive fire protection (i.e. fire barriers).

Based on tests performed using a cone calorimeter, H-TRIS or environmental chamber, it can be concluded (regarding nonmetallic connections with a fibre-reinforced phenolic dowel and a DVW flitch plate in a fire) that

- the heat transfer along the dowel was governed by the timber

no visual effect of the dowel on the char formation in the timber was observed

- embedment failure was less likely to occur with non-metallic than with metallic connections.

Tests in an environmental chamber with the specific tested configurations and conditions concluded that

- failure of the metallic connections occurred faster than failure of the non-metallic connections under sustained loads of 20 and $40 \%$ of the ambient connection capacity

- the most significant differences were seen at the lower load levels

- flitch plate failures limited the fire performance of the nonmetallic connections with a $20 \%$ load level.

The heat transfer tests conducted with the novel H-TRIS device or a cone calorimeter concluded that

- the timber (LVL) showed more variation in thermal properties than the DVW

- the temperature evolution in the in-plane direction of DVW was slower than the temperature evolution measured in the LVL

- in a connection, the heat transfer in the LVL along the flitch plate was reduced by the flitch plate material

- an intumescent sealant can be used to successfully protect the flitch plate

- this intumescent sealing can enhance the fire performance of the non-metallic connection.
Conclusions regarding metallic connections are drawn from mechanically loaded tests and confirm the results of previous studies (Carling, 1989; Leicester et al., 1979), namely that unprotected metallic dowels and flitch plates of a timber connection rapidly conduct heat into the connections; this softens the timber adjacent to the metallic members, where the stresses are high, and increases char formation in timber adjacent to the metallic members. Therefore embedment failure is the predominant failure mode for these metallic connections in fires. Finally, an increase of dimensions of the metallic connection will only lead to a limited increase of fire performance. Increasing the dimensions of the non-metallic connection will, on the other hand, result in a much more significant increase of fire performance.

The findings lead to an improved fire performance of dowelled timber connections, which can lead to a significant improvement of the fire performance of whole timber structures. Future research steps will be structural modelling of the metalfree connections in fire and developing simplified design rules for practical use.

\section{Acknowledgements}

The authors are very grateful to the BRE TRUST for its financial support.

\section{REFERENCES}

Aseeva R, Serkov B and Sivenkov A (2014) Fire Behavior and Fire Protection in Timber Buildings. Springer, Wien, Austria.

Bank LC (2006) Composites for Construction: Structural Design with FRP Materials. Wiley, Hoboken, NJ, USA.

Bisby L, Gales J and Maluk C (2013) A contemporary review of large-scale non-standard structural fire testing. Fire Science Reviews 2(1): 1-27.

Brandon D, Ansell MP, Harris R, Walker P and Bregulla J (2013) Modelling of non-metallic timber connections at elevated temperatures. Materials and Joints in Timber Structures 9(1): 231-241.

BSI (1991) BS EN 26891:1991. Timber Structures. Joints Made with Mechanical Fasteners. General Principles for the Determination of Strength and Deformation Characteristics. BSI, London, UK.

BSI (2002) BS ISO 5660-1. Heat Release, Smoke Production and Mass Loss Rate. Part 1: Heat Release Rate (cone Calorimeter Method). BSI, London, UK.

BSI (2004) BS EN 1995-1-1:2004. Eurocode 5: Design of Timber Structures - Part 1.2: General - Structural Fire Design. BSI, London, UK.

BSI (2012) BS EN 1363-1:2012: Fire Resistance Tests - Part 1: General Requirements. BSI, London, UK.

Buchanan AH (2002) Structural Design for Fire Safety. Wiley, Chichester, UK. 
Carling O (1989) Fire Resistance of Joint Details in Load Bearing Timber Construction - A Literature Survey. Building Research Association of New Zealand, Porirua, New Zealand, BRANZ Study Report SR18.

Drake RD, Aram JWE and Ansell MP (1998) The performance of pultruded GRP connectors in multiple dowelled double shear timber joints. Journal of the Institute of Wood Science 14(6): 277-283.

FPL (2010) Wood Handbook: Wood as an Engineering Material. Forest Products Laboratory (FPL), US Department of Agriculture, Madison, WI, USA, General Technical Report FPL-GTR-190.

Frangi A (2001) Brandverhalten von Holz-Beton-Verbunddecken (in German). PhD thesis, Eidgenössische Technische Hochschule (ETH) Zürich, Zürich, Switzerland. See http://e-collection.library.ethz.ch/eserv/eth:24596/eth-2459601.pdf (accessed 09/02/2015).

Frangi A, Erchinger C and Fontana M (2010) Experimental fire analysis of steel-to-timber connections using dowels and nails. Fire and Materials 34(1): 1-19.

Gerard R, Barber D and Wolski A (2013) Fire Safety Challenges of Tall Wood Buildings. Arup North America, San Francisco, CA, and Fire Protection Research Foundation, Quincy, MA, USA.

Gottfried JS, Rein G, Bisby LA and Torero JL (2010) Experimental review of the homogeneous temperature assumption in post-flashover compartment fires. Fire Safety Journal 45(4): 249-261.

Harmathy TZ and Lie TT (1970) Fire test standard in the light of fire research. In Fire Test Performance - ASTM Special Technical Publication 464 (Shorter G (ed.)). American Society for Testing and Materials, Philadelphia, PA, USA, pp. 85-97.

Law A, Gottfried JS, Gillie M and Rein G (2011) Structural engineering and fire dynamics: advances at the interface. Fire Safety Science 10(1): 1563-1576.

Leicester RH, Seath C and Pham L (1979) The fire resistance of metal connectors. In Proceedings of the Nineteenth Forest Products Research Conference, Melbourne, Australia. (Leicester RH (ed.)). CSIRO, Melbourne, Australia, pp. 16-24.

Leijten AJM, Ruxton S, Prion H and Lam F (2006) Reversed-cyclic behavior of a novel heavy timber tube connection. Journal of Structural Engineering 132(8): 1314-1319.

Maluk C (2014) Development and Application of a Novel Test Method for Studying the Fire Behaviour of CFRP Prestressed Concrete Structural Elements. PhD thesis, The University of Edinburgh, Edinburgh, UK.

Moss PJ, Buchanan AH, Fragiacomo M, Lau PH and Chuo TC (2009) Fire performance of bolted connections in laminated veneer lumber. Fire and Materials 33(5): 223-243.
Naughton A, Fan M and Bregulla J (2014) Fire resistance characterisation of hemp fibre reinforced polyester composites for use in the construction industry. Composites Part B 60(1): 546-554.

Östman BAL and Tsantaridis LD (1994) Correlation between cone calorimeter data and time to flashover in the room fire test. Fire Materials 18(4): 205-209.

Östman BAL, Mikkola E, Stein R et al. (2010) Fire Safety in Timber Buildings-Technical Guideline for Europe. Technical Research Institute of Sweden, Stockholm, Sweden, SP Report 2010:19.

Palma P, Frangi A, Hugi E, Cachim P and Cruz H (2014) Fire resistance tests on beam-to-column shear connections. In Proceedings of the 8th International Conference on Structures in Fire (Li GQ, Jiang SC and Chen SW (eds)). Tongji University Press, Shanghai, China, pp. 545-556. Pedersen MU (2002) Dowel Type Timber Connections Strength Modelling. Danmarks Tekniske Universitet, Lyngby, Denmark, Report BYG DTU R-039 2002.

Peng L, Hadjisophocleous G, Mehaffey J and Mohammad M (2010) Fire resistance performance of unprotected wood-wood-wood and wood-steel-wood connection: a literature review and new data correlations. Fire Safety Journal 45(6-8): 392-399.

Sachs EO (1903) Suggested standards of fire resistance. In Proceedings of the International Fire Prevention Congress, London, UK (Ira H and Woolson EM (eds)). Martin B Brown Co, New York, NY, USA, pp. 249-252.

Thomson A, Harris R, Ansell MP and Walker P (2010) Experimental performance of non-metallic mechanically fastened timber connections. The Structural Engineer 88(17): 25-32.

\section{WHAT DO YOU THINK?}

To discuss this paper, please email up to 500 words to the editor at journals@ice.org.uk. Your contribution will be forwarded to the author(s) for a reply and, if considered appropriate by the editorial panel, will be published as discussion in a future issue of the journal.

Proceedings journals rely entirely on contributions sent in by civil engineering professionals, academics and students. Papers should be 2000-5000 words long (briefing papers should be 1000-2000 words long), with adequate illustrations and references. You can submit your paper online via www.icevirtuallibrary.com/content/journals, where you will also find detailed author guidelines. 